\title{
The Road to Recovery: A Comparative Analysis of the Impact of the Financial Crisis on the Rights of Workers in Greece, Portugal, France and the United Kingdom and their Insolvency Legal Systems
}

\author{
By: Jennifer L. L. Gant ${ }^{1}$ and Alexandra Kastrinou $\mathrm{PhD}^{2}$
}

\section{Introduction}

The financial crisis and the sovereign debt crisis that followed it have been attributed to a number of causes. Whether these are economic, social, cultural or legal, they are all by and large also political. The aim of this paper is not to delve into the myriad of heated political arguments that continue to dominate the scene, but to assess the impact of the financial crisis on workers' rights in Greece, Portugal, France and the United Kingdom and to examine its impact on their corporate rescue regimes with a view to understanding what the legislative and social changes may mean for the future of these individual nations, their people and businesses, and perhaps for the EU and Eurozone as a whole. In light of the crisis, the rights of the workforce have been severely compromised in order to alleviate pressures on troubled companies and to afford them a greater potential for recovery. In response to the crisis, all four jurisdictions have introduced reforms to their labour codes and corporate rescue mechanisms in order to minimise the catastrophic impact on their economies and societies.

As a project, this is only the beginning. This paper will only offer a snap shot of those important changes that have occurred since the crisis began, the effects as understood at the current level of research, and an initial assessment as to whether or not the reforms of the pre-insolvency regimes in particular have operated as an effective embankment for the protection of social and economic welfare, the former of these being already significantly reduced throughout the EU. While France and the UK have had their fair share of economic hardships, Greece and Portugal were forced to go to the International Monetary Fund, European Commission and the

\footnotetext{
${ }^{1} \mathrm{PhD}$ Candidate in Insolvency, Employment and Comparative Law at Nottingham Trent University supervised by Professors David Burdette and Paul Omar.

${ }^{2}$ Senior lecturer in Law at Nottingham Law School, Nottingham Trent University.
} 
European Central Bank $^{3}$ for assistance in order to avoid defaulting on sovereign loans, an outcome that would have had a severe effect on financial markets throughout the EU. This assistance was granted in exchange for their agreement to the terms of Memoranda of Understanding ${ }^{4}$ that set out measures to be taken to improve their economic viability and market flexibility. The austerity measures implemented in response to the MoUs have caused great hardship and social turmoil in both Greece and Portugal. ${ }^{5}$

\section{The Impact of the Financial Crisis on Workers Rights}

While not every jurisdiction has suffered the same reduction in workers' rights, every country has taken some steps within their labour and employment legal systems with a view to improving their economic position by enhancing market flexibility. Fundamental changes to working time and atypical employment (albeit often temporary) have been made throughout the EU in response to the economic crisis. Changes to redundancy rules and industrial relations structures and processes have also occurred, often affecting the social dialogue by engaging in measures to decentralise collective bargaining. Regardless of whether such changes are permanent, they have the effect of undermining the protective role of labour and employment law, placing workers in a more precarious position than they would have enjoyed prior to the financial and sovereign debt crisis. ${ }^{6}$ Pensions have also been significantly affected by the crisis throughout the EU, which may have lasting implications as the working generations move into retirement. Whether due to the terms of a MoU or to policy changes to meet the needs of the times, each jurisdiction under examination has engaged in a process of reforming labour laws in order to increase labour market flexibility in the hopes that this would help to repair national economies in crisis.

\section{Greece}

\footnotetext{
${ }^{3}$ Often referred to as the "troika", which is how they will be referred to hereafter in this paper.

${ }^{4}$ Referred to hereafter as "MoU"'

${ }^{5}$ For more detail on the financial and sovereign debt crises, see for example F. Pavoncello, "One for All, All for One: The Euro in Crisis", (2011) May/June World Affairs, pp. 59-70; J. A. Caporaso and Min-Hyung Kim, "The Maastricht Treaty at Twenty: A Greco-European Tragedy?" (2012) 34(7) European Integration, pp. 769-789; C. Hadjmichalis, "Uneven Geographical Development and Socio Spatial Justice and Solidarity: European Regions after the 2009 Financial Crisis", (2011) 18 European Urban and Regional Studies, pp. 254-274; C. Barnard, "The Financial Crisis and the Euro Plus Pact: A Labour Lawyer's Perspective", (2012) 41(1) Industrial Law Journal, pp. 98-114; and M. Ferrera, "Social Europe and its Components in the Midst of the Crisis: A Conclusion", (2014) 37(4) West European Politics, pp. 825-843.

${ }^{6}$ S. Clauwaert and I. Schomann, "The Crisis and National Labour Law Reforms", (2012) Working Paper 2012.04 European Trade Union Institute at 8-14.
} 
Greece initially took steps in line with the protective function of labour law during at the beginning of the crisis but its perspective changed completely as time has passed and its $\mathrm{MoU}$ came into effect. ${ }^{7}$ The financial crisis revealed endemic weaknesses in the Greek welfare system and employment regime, in part due to the dualist labour market comprised of an official public pool that makes its contributions and is protected by the employment laws in place, and a shadow labour market that is subject to the precariousness of the poor economic climate and is not generally entitled to the same level of social protection. Thus when Greece had to resort to the troika for rescue, the austerity measures imposed by the MoU had a particularly severe impact on those citizens engaged in the shadow labour market. ${ }^{8}$ The overall goals of the MoU were to eliminate fiscal imbalances by achieving fiscal surpluses; to improve competitiveness; and to improve liquidity for Greece until its return to the financial markets. ${ }^{9}$

When the austerity measures were implemented, there was a rapid reduction of salaries in the public sector, which were transmitted quickly to the private sector, reducing the purchasing power of the Greek people. This in turn created a deep and persistent recession, leading to a steep rise in unemployment. Greece also had to focus on reducing its debt burden, which diverts public expenditure from social benefits, health, education, and welfare provisions. Unemployment has continued to rise, and as of October 2014 was hovering at $27 \%$. The level and depth of poverty and personal despair has intensified, not the least due to the fact that the unemployment fund is based exclusively on contributions, to which those who had previously worked in the shadow economy or as undeclared workers will not have contributed. The social protection available to ameliorate the severe impact of high unemployment is wholly inadequate to the nature of the Greek labour market. ${ }^{10}$

The structural reforms to labour law specifically were undertaken based on the premise that labour market regulation constituted a significant barrier to growth. Prior to the crisis, there had been significant resistance to any flexibilisation of the labour market through the implementation of laissez-faire policies on collective bargaining. By the time of the crisis, Greece had some of the strictest employment protection legislation in the EU. ${ }^{11}$ In counterpoint to Greece's previously extremely employee friendly policies, the austerity policies applied under its $\mathrm{MoU}$ are among

\footnotetext{
${ }^{7}$ C. Papadimitriou, "The Greek Labour Law Face to the Crisis: A Dangerous Passage Towards a New Juridical Nature”, (2013) European Labour Law Network - Working Paper Series, ELLN Working Paper 3/2013 at 4.

${ }^{8}$ C. Dimoulas, "Exploring the Impact of Employment Policy Measures in the Context of Crisis: The Case of Greece", (2014) 67(2) International Social Security Review, pp. 49-65, at 49-55.

${ }_{9}^{9}$ S. Zartaloudis, "The Impact of the Fiscal Crisis on Greek and Portuguese Welfare States: Retrenchment before the Catch-up?", (2014) 48(4) Social Policy and Administration, pp. 430-449, at 438.

${ }^{10}$ C. Dimoulas, op. cit., at 49-55.

11 A. Koukiadaki and L. Krestos, "Opening Pandora's Box: The Sovereign Debt Crisis and Labour Market Regulation in Greece”, (2012) 41(3) Industrial Law Journal, pp. 276-304, at 278-280.
} 
the most severe in Europe since the end of the Second World War. ${ }^{12}$ Employment remains highly fragile in those economies, such as that of Greece, that have been subject to austerity measures and where business restructuring and its effect on job security is an ongoing reality. ${ }^{13}$

\section{i) Wages}

The minimum wage has been decreased by approximately $22 \%$ for adults and $32 \%$ for youths under $25 .{ }^{14}$ Public sector employees have suffered a flat reduction in monthly salary as well as holiday and annual leave premiums. Pay is also frozen and can no longer be the increased through collective bargaining. Overall, wages have decreased by an average of $50 \%$ since the beginning of the sovereign debt crisis. This is due in part to the decrease in overtime pay, rendering the labour force less expensive and more flexible. ${ }^{15}$ In addition, partial unemployment has been introduced as a measure permitting a company to employ employees for a number of days less than provided for in their employment contract along with the commensurate reduction in pay. ${ }^{16}$

\section{ii) Atypical Contracts}

Changes in the rules governing atypical work contracts have also introduced an element of labour flexibility with its associated loss in job security. Greece has changed its rules on fixed term contracts, increasing the maximum term from two to three years. ${ }^{17}$ There is also an increased utilisation of rotational work and fixed term contracts in order to increase flexibility. ${ }^{18}$ However, Greece has also introduced a new scheme for the protection of employees on reduced working hours in medium sized companies. ${ }^{19}$ A number of new kinds of employment contracts have also been created that effectively reduce the protection that normal employment would provide. For example, a "youth contract" has been introduced through which young workers are hired on wages $20 \%$ less than the previous rate for first job, with a two

\footnotetext{
${ }^{12}$ C. Hadjimichalis, "Uneven Geographical Development and Socio Spatial Justice and Solidarity: European Regions after the 2009 Financial Crisis", (2011) 18 European Urban and Regional Studies, pp. 254-274, at 268.

${ }_{13}$ A. Muller, "Employment Protection Legislation Tested by the Economic Crisis: A Global Review of the Regulation of Collective dismissals for Economic Reasons”, (2011) International Labour Office, Dialogue in Brief No. 3.

${ }^{14}$ C. Dimoulas, op. cit, at 54

${ }^{15}$ C. Papadimitriou, "The Greek Labour Law Face to the Crisis: A Dangerous Passage towards a New Juridical Nature", (2013) European Labour Law Network - Working Paper Series, ELLN Working Paper 3/2013, at $9 \& 12$

${ }^{16}$ C. Papadimitriou, op. cit., at 9.

${ }^{17}$ S. Clauwaert and I. Schomann, op. cit., at 11.

${ }^{18}$ C. Dimoulas, op. cit., at 54.

${ }^{19}$ D. Clegg, "Labour Market Policy in the Crisis: the UK in Comparative Perspective", (2010) 18(1)

The Policy Press, pp. 5-17, at 11.
} 
year trial period, no social contributions from employers and no entitlement to unemployment benefits at the end of the contract. ${ }^{20}$

\section{iii) Hiring and firing}

One of the most significant austerity measure taken in relation to labour market flexibility relates to the reduction of the costs of hiring and firing. ${ }^{21}$ Greek law does not require an employer to justify the dismissal of an employee as a potentially fair reason, an aspect of its labour code that was in place prior to the crisis. However, severance packages were so generous that its labour system was still considered highly inflexible. Following the crisis, notification periods were significantly reduced thereby reducing the potential amounts of severance compensation, therefore reducing the cost of dismissal. ${ }^{22}$ While justified in the name of competitiveness, these changes may also promote the adoption of a short term solution for reducing costs via dismissals, rather than pursuing longer term strategies, further undermining employment security. ${ }^{23}$

\section{iv) Redundancy}

Collective redundancies, an action often taken when companies fall into financial distress, are governed by the Collective Redundancies Directive, ${ }^{24}$ which stipulates information and consultation obligations for employers planning to make a minimum of 10 employees in a company with more than 20 employees and $10 \%$ in establishments with at least 100 employees. Greece's original implementation was far more generous, providing for the Directive's obligations to apply in cases when 4 employees were to be dismissed in enterprises of more than 20 employees and $2 \%$ of employees in enterprises with 150 or more employees. While the law of 2010 raised this to 6 employees in 20 and 5\% in enterprises of more than 150 employees, it still remains far more protective than the minimum requirements relative to the Directive's implementation in other member states. However, redundancy pay has been reduced by $50 \%{ }^{25}$

\section{v) Collective Bargaining}

\footnotetext{
${ }^{20}$ S. Clauwaert and I. Schomann, op. cit., at 11.

${ }^{21}$ C. Dimoulas, op. cit., at 56.

${ }^{22}$ C. Papadimitriou, op. cit., at 9.

${ }^{23}$ A. Koukiadaki and L. Krestos, op. cit., at 286-287.

${ }^{24}$ Directive $98 / 59 / \mathrm{CE}$ of 1998 on the approximation of the laws of the Member States relating to collective redundancies (OJ L 225/16).

${ }^{25}$ A. Muller, op. cit., at 4; C. Dimoulas, op. cit., at 54; and A. Koukiadaki and L. Krestos, op. cit., at 287.
} 
The fundamental nature of Greek collective bargaining has changed in the wake of the crisis as aspects that had formed part of the industrial character have been wholly displaced. The hierarchy of collective agreements has changed; the potency of branch level collective agreements has reduced; the extension period for agreements following their expiry has been reduced; and mandatory arbitration in the settlement of disputes has been abandoned. ${ }^{26}$ Representation criteria of social partners have been reviewed and trade union prerogatives have been extended to other worker representation bodies. ${ }^{27}$ Greece has also placed legal restrictions on the role of collective bargaining through the prohibition of wage increases until the unemployment rate reduces below $10 \% .{ }^{28}$ There are also ongoing negotiations with the troika exploring the possibility of unilaterally limiting the employee right to strike.

\section{vi) Access to Social Welfare}

Greece has tightened restrictions on the access to social benefits as well as reducing the duration and level of payments as a part of their austerity measures. Further, the "workfare" employment measure has expanded the use of fixed-term, quasiemployment in the community and public services, providing a minimum fixed income but few employment rights. Under the workfare rules, unemployed youth, long term unemployed, and the working poor with low annual incomes are granted five months of employment benefit in exchange for working six hours per day in community services. These workers replaced the need to hire within the public service, which had been frozen under the MoU. ${ }^{29}$ However, Greece has introduced subsidies for employers who recruit unemployed workers. ${ }^{30}$

\section{Portugal}

The labour market in Portugal shares some similarities to that in Greece in that it also of a dual character. A large proportion of workers in large enterprises and the public sector enjoyed a high level of employment protection, while those in micro, small and medium sized enterprises are less privileged as these companies often do not respect employment protection legislation and therefore demonstrate a high level of flexibility in hiring and firing. It is this latter labour sector that tends to be the hardest hit in times of crisis and explains the rapid rise in unemployment that

\footnotetext{
${ }^{26}$ C. Papadimitriou, op. cit., at 16-17.

${ }^{27}$ S. Clauwaert and I. Schomann, op. cit., at $10 \& 14$

${ }^{28}$ C. Dimoulas, op. cit, at 54.

${ }^{29}$ Ibid., at 56 and 59.

${ }^{30}$ D. Clegg, op. cit., at 9.
} 
occurred in similar fashion to Greece, despite the differences in the systems. ${ }^{31}$ However, a unique aspect of the Portuguese economy is that its constitutional and legal order significantly empowers the more organised segments of the workforce. Prior to its bail-out, Portugal had the most rigid employment protection laws in the Eurozone..$^{32}$ Among developed nations it ranked last in terms of labour freedom ${ }^{33}$ and it has been asserted that such rigidity has impaired firm performance. ${ }^{34}$ While joining the Euro had the effect of impairing Portugal's ability to provide cheap products to the European market due to the levelling effect of the common currency, its highly rigid and protective labour system are also at the root of Portugal's competitiveness problem, but it is also an inherently political issue. ${ }^{35}$

Portugal began to feel the pinch of recession shortly after joining the Euro due to its low level of competitiveness in the Common Market. It first introduced austerity measures in 2005 to combat the depth of recession, and again in 2010. In March 2011, in order to avoid a failure requiring the resort to external rescuers, additional measures were introduced that would have made cuts to welfare and health, as well as freezing pensions, but this was not approved by parliament. Thus Portugal also resorted to the troika for help and agreed to its own MoU, implementing cuts that went well beyond those suggested therein. ${ }^{36}$ The Memorandum of Understanding specifically targeted several areas in need of labour reform: reduction of long term unemployment and strengthening social protections; reform of the employment protection legislation in order to combat the segmentation of the labour market and to facilitate the movement of workers between professions, markets and sectors; improve flexibility of working time rules in order to fit the needs of peak business times and thus augment the competitiveness of Portuguese businesses; to connect the costs of labour with effective job creation; and to approve legislation that serves to improve the employability of youth and of other traditionally disadvantaged categories of workers. ${ }^{37} \mathrm{~A}$ new labour code entered into force on 1 August 2012 which attempted to integrate the changes required in the

\footnotetext{
${ }^{31}$ J. M. Magone, "Portugal is not Greece: Policy Responses to the Sovereign Debt Crisis and the Consequences for the Portuguese Political Economy" (2014) 15(3) Perspectives on European Politics and Society, pp. 346-360, at 349-350.

${ }^{32}$ G. Bragues, "Portugal's Plight: The Role of Social Democracy", (2012) 16(3) The Independent Review, pp. 325-349, at 338-339.

${ }^{33}$ J. A. Vasconcellos, "Portuguese Institute for Economic Freedom", available from <http://institutoliberdadeeconomica.blogspot.co.uk/> accessed 24 September 2014.

${ }^{34}$ P. S. Martins, "Dismissals for Cause: The Differences that just Eight Paragraphs can Make", (2009)

27 Journal of Labour Economics, pp. 257-279.

${ }^{35} \mathrm{G}$. Bragues, op. cit, at 339 .

${ }^{36} \mathrm{~S}$ Zartaloudis, op. cit., at 437-443.

${ }^{37}$ A. P. Nascimento, "Relaciones Laborales y Regulacion de los Sistemas de Prevision Social: A Reforma Laboral em Portugal" (2012) Actualidad Jurídica Uría Menéndez, Especial reformas estructurales, pp. 47-61 available from the following web link:

<http://www.uria.com/documentos/publicaciones/3603/documento/a5.pdf?id=4410> accessed 15 August 2014, at 48 .
} 
MoU, under a flurry of cries against the constitutionality of the reforms, which were summarily ignored by the government in power at the time. ${ }^{38}$

\section{i) Wages}

Pay freezes were introduced for public sector workers as were freezes on promotions. Salaries were cut by between 3.5 and $10 \%$ in 2010. Salary and holiday bonuses were abolished. ${ }^{39}$ In addition, and as a subset of a reduction in wages, the Portuguese MoU has had a considerable effect on the reform of working time rules, widening overtime options significantly. Previously, employees were paid 50\% of their hourly wage for the first hour of overtime, $75 \%$ for additional hours and $100 \%$ for work on holidays and Sundays. These rewards have now been reduced by half. ${ }^{40}$ In addition, the working week was been increased from 35 to 40 hours for public sector workers and extended normal working hours for all employees by two hours per day in order to cut overtime costs. Four public holidays have also been abolished. ${ }^{41}$

\section{ii) Hiring and Firing}

Prior to the reforms to the labour code, the Portuguese constitution prohibited dismissals without a just cause or for political or ideological reasons. Essentially, it was impossible to dismiss an employee who had not behaved in an illicit or deviant manner having such gravity that it effectively destroyed the employment relationship. ${ }^{42}$ Following the introduction of the new labour code, there has been an extension in the concepts of unsuitability and the extinction of worker positions in order to make individual dismissals easier. An employer can now establish nondiscriminatory criteria for dismissals, drawing Portugal's redundancy rules in line with what currently exists in the UK. Employers are also no longer obliged to offer a transfer to another suitable position when dismissing an employee for either unsuitability or the extinction of his job. ${ }^{43}$

Portugal has also reduced severance pay for workers from 30 days for every year of service with no maximum limit with a three month minimum to 20 days per year of service with no minimum severance pay with a cap at 12 months wages or 240 times the minimum wage. Further reforms have been announced that will bring

\footnotetext{
38 "Controversial New Labour Code Comes into Force” European Industrial Relations Observatory Online, available from <http://www.eurofound.europa.eu/eiro/2012/05/articles/pt1205019i.htm> accessed 26 September 2014.

${ }^{39}$ S. Zartaloudis, op. cit., at 441.

${ }^{40}$ S. Clauwaert and I. Schomann, op. cit., at 8-9.

${ }^{41}$ S. Zartaloudis, op. cit., at 442.

${ }^{42}$ A. P. Nascimento, op. cit., at 50.

43 "Controversial New Labour Code Comes into Force” op. cit.
} 
the Portuguese severance packages into line with EU averages. Probationary periods for new employees have also been raised from 3 to 6 months. ${ }^{44}$

\section{iii) Atypical Contracts}

Portugal has also rendered the rules on fixed term contracts more flexible by increasing the maximum length of a fixed term contract from 6 months to 3 years ${ }^{45}$ with the potential to renew twice. ${ }^{46}$ These changes, in addition to the changes to dismissal rules generally, have seen a shift away from indeterminate contracts toward fixed term contracts due to the constitutionally imposed difficulties of ending indeterminate term contracts, ${ }^{47}$ rendering job security far more precarious for many workers.

\section{iv) Redundancies}

Prior to reforms, the system governing collective redundancies in Portugal was rigid requiring verification of the reasons for the dismissals and strict formal procedures. ${ }^{48}$ More flexible redundancy legislation has been introduced affecting the costs of layoffs and other measures to reduce the financial burden on undertakings themselves. Eligibility and qualification periods have been amended, providing more scope for worker dismissal, and redundancy benefits have been reduced. In addition, Portugal has introduced an "employers' compensation fund" to finance redundancy benefits. ${ }^{49}$

\section{v) Collective Bargaining}

Portugal has also undergone amendments to the procedures governing collective bargaining aimed at flexibilising existing legislation. ${ }^{50}$ It has pushed for more firm level collective agreements and even individual agreements between employers and employees. ${ }^{51}$ There has been a move toward making it possible for lower level bargaining to deviate unfavourably from higher level collective agreements or even statutory legislation. The representation criteria of social partners have also been reviewed and trade union prerogatives have been extended to other bodies of worker

\footnotetext{
${ }^{44}$ S. Zartaloudis, op. cit., at 442.

${ }^{45}$ S. Clauwaert and I. Schomann, op. cit., at 11.

${ }^{46}$ A. P. Nascimento, op. cit., at 51.

${ }^{47}$ Ibid.

${ }^{48} \mathrm{Ibid}$., at 50.

${ }^{49}$ S. Clauwaert and I. Schomann, op. cit., at 12-13.

${ }^{50}$ Ibid

${ }^{51}$ S. Zartaloudis, op. cit., at 442.
} 
representation..$^{52}$ Portugal has also made it impossible to bargain for conditions better than the new labour code has put into place. ${ }^{53}$ The overall effect of these moves toward decentralisation of trade union operations will serve to weaken trade union action and representation at all levels of bargaining. It will also weaken the acquired social rights achieved by trade unions at national and local levels throughout the EU, lower the standard of recognised rights, and affect fundamental employment conditions and social protections. ${ }^{54}$

\section{vi) Access to Social Welfare}

The maximum amount of unemployment insurance has been reduced by a third (from three times to only twice the social support index), and the maximum length of time the benefit could be paid was reduced from 900 to 540 days. ${ }^{55}$ However, there has also been an increase in the maximum duration of entitlement to noncontributory social benefit for unemployment schemes. ${ }^{56}$

\section{France}

The plight of Greece and Portugal are only slightly reflected in the effects that have been felt on the welfare states of central Europe, such as France. Many states have reformed in ways that reduce entitlements, protection and the welfare of precarious or unemployed workers. Temporary working has also become more common, which has wide ranging implications for worker equality due to lower employment security and earning power. However, while these issues have become common throughout the Eurozone and the UK, France's protection for temporary workers has remained the highest in Europe, despite an apparent need to deregulate temporary work in order to inject flexibility in the labour market and deal with high unemployment rates like the rest of the EU. ${ }^{57}$ Further, France has introduced additional protections and assistance for their unemployed, including subsidised employment contracts and extended to new groups of workers a Professional Transition Contract that provides intensive help with a job search over a twelve month period, during which a beneficiary is also entitled to higher benefit payments. ${ }^{58}$

The French banking sector was also not as severely compromised by the financial crisis as were the systems of the UK and Germany. This has been in part attributed to the way in which France internationalised its banking sector with what has been viewed as a more diverse approach with a combination of retail investment

\footnotetext{
${ }^{52}$ S. Clauwaert and I. Schomann, op. cit., at 10 \& 14.

53 "Controversial New Labour Code Comes into Force" op. cit.

${ }^{54}$ S. Clauwaert and I. Schomann, op. cit., at $10 \& 14$.

55 "Controversial New Labour Code Comes into Force" op. cit.

${ }^{56}$ D. Clegg, op. cit., at 12.

${ }^{57}$ T. Vlandas, "The Politics of Temporary Work Deregulation in Europe: Solving the French Puzzle", (2013) 41 Politics \& Society, pp. 425-460, at 426-417.

${ }^{58}$ D. Clegg, op. cit., at 9.
} 
as well as corporate lending and investment banking, the latter two of course being the cause of much of the banking turmoil that caused the crisis. Although French banks were still heavily engaged in market-based banking, they were far smaller investors in toxic assets and other high risk activities. ${ }^{59}$ Throughout the crisis, soft forms of protectionism and limited foreign penetration remained features of the French banking system while there was only an initial and temporary upswing of intervention as a result of the crisis. ${ }^{60}$ There have, however, been a number of changes to the French labour code during this period.

\section{i) Wages}

Short time working regimes, which refer to the option of an employer to essentially "lay off" employees for a period of time each week or to reduce working hours on a daily basis in order to save money for the company regimes, were introduced in France as a result of the financial crises. ${ }^{61}$ These regimes resulted in an overall reduction in wage levels throughout the labour market.

\section{ii) Hiring and Firing}

The statute of limitations for claims relating to the performance or termination of an employment contract has been reduced from five to two years and to three years for salary related claims (in stark contrast to the 3 months limitation period in the UK for employment tribunal claims!) France has also introduced an enticement to engage in alternative dispute resolution by introducing minimal lump sum compensation for employees willing to settle at a conciliation hearing before the labour court in dismissal cases. ${ }^{62}$

\section{iii) Redundancies}

In May 2013 France passed a Job Security Bill that introduced a number of reforms to their labour code relating to the rules governing collective redundancies. The new legislation affords employers a greater choice as to the procedure they follow when considering collective redundancies in a company of more than 50 employees or

\footnotetext{
${ }^{59}$ D. Howarth, "France and the International Financial Crisis: The Legacy of State Led Finance", (2013) 26(3) Governance: An International Journal of Policy, Administration, and Institutions, pp. 369-395, at $374 \& 377-382$.

${ }^{60}$ D. Howarth, op. cit., at $374 \& 389$.

${ }^{61}$ S. Clauwaert and I. Schomann, op. cit., at 10.

${ }^{62}$ J.-F. Gerard, "International Labour Law Bulletin”, Freshfields Bruckhaus Deringer Summer 2013 available

from 〈http://www.freshfields.com/uploadedFiles/SiteWide/Knowledge/36343_FINAL\%20PDF.pdf〉 first accessed 26 September 2014.
} 
more than 10 within 30 days, triggering a job protection plan. Employers are now able to negotiate an agreement with a relevant trade union or to unilaterally implement a "social plan", which allows employers to depart significantly from standard requirements governing the number of meetings with employee representatives, timetables for dismissals, and selection criteria with the aim of speeding up the collective consultation process. Works Councils will also be deemed to have been consulted even if it fails to respond within a now closed timeline. Employers are also now permitted to enter into agreements with trade unions under which employees agree to detrimental changes to their terms and conditions in return for a commitment by the employer not to implement any redundancies during the term of the agreement. ${ }^{63}$

France has also added additional protections following the financial crisis. It adopted a law specifying that in the event that collective redundancies result in the offer of a new post abroad, remuneration must be equivalent to that paid in France. Further, the Court of Cassation ruled that contracts terminated by mutual consent for economic reasons in the context of a workforce reduction should also be counted within the number of intended redundancies, thus counting toward the thresholds of collective redundancies, which may then indicate the requirement for an employment safeguard plan to be put in place. Termination by mutual agreement can therefore not be used to circumvent the protections in place for employees subject to redundancy. ${ }^{64}$

\section{iv) Access to Social Welfare}

France has extended the maximum duration of compensated partial or technical unemployment and increased its compensation rates for the same. In addition, it has made it easier to access the benefit system for those with short working records. ${ }^{65}$ France has also extended its unemployment insurance agreement to better benefit the most precarious workers by reducing the minimum contribution period for unemployment insurance entitlement from four to six months. In addition, France is offering one off 500 Euro payments for young people who lack a substantial work history. Finally, the Professional Transition Contract has now been extended to workers in companies of all sizes and offers $80 \%$ replacement of previous gross salary and intensive job-seeking assistance for a year to those workers who have been made redundant for economic reasons. ${ }^{66}$

\footnotetext{
${ }^{63}$ Ibid. and J.-M. Sainsard and C. Noblet, "France Introduces Radical Labour Market Reforms", Squire and

Sanders, available from and <http://www.squiresanders.com/files/Publication/5fdc90a3-c1d2-4c6ab71d-ab4fc7429426/Presentation/PublicationAttachment/0fbce787-35f0-4c05-becdb2a7e4620235/France-Introduces-Radical-Labour-Market-Reforms-Newsletter.pdf>, first accessed 26 September 2014.

${ }^{64}$ A. Muller, op. cit., at 8.

${ }^{65} \mathrm{D}$. Clegg, op. cit., at 11.

${ }^{66} \mathrm{Ibid}$., at 13.
} 


\section{v) Collective Bargaining}

There has been a move toward making it possible for lower level bargaining to deviate unfavourably from higher level collective agreements or even statutory legislation. ${ }^{67}$ Thus France is also taking small steps toward the decentralisation of collective bargaining.

\section{The United Kingdom}

While the UK experienced a sudden economic shock in terms of bankruptcies, decrease in consumer demand, drops in gross domestic product growth and an increase in unemployment, it differs from France, Greece and Portugal in several significant ways. It is not part of the Single Monetary Union, it follows a liberal approach to the economy and a light touch to any kind of interventionist regulation, ${ }^{68}$ which was only enhanced through deregulation as a result of the economic crisis, and its financial structure is highly internationalised. As a result of this latter characteristic, it was one of the first European countries to be heavily hit by the global crisis, due to its strong ties with the financial sector of the United States. ${ }^{69}$

In terms of social and unemployment problems precipitated by the financial crisis, Britain has taken a distinctly laissez-faire approach, being unwilling to improve, even temporarily, the already relatively low support provided in unemployment. The UK's approach to tackling the crisis has been characterised mostly by tax cuts in an attempt to boost economic activity while nothing has been done to address those who are becoming unemployed, differing significantly in approach to the rest of Western Europe. ${ }^{70}$ In addition, the UK has proceeded to deregulate the labour market in a number of areas, including discrimination and equality. It has repealed provisions in the Equality Act 2010 relating to combined protective characteristics and third party harassment on the grounds that they are perceived as burdens on business. The duty on public authorities to have regard to the need to reduce socio-economic inequalities has been repealed (though it also never entered into force) and the duty on large employers to publish details of the gender pay gap is not being implemented. ${ }^{71}$

The UK has also implemented a new employee-shareholder status in which employees can agree in exchange for shares with a minimum value of $£ 2000$ in the

\footnotetext{
${ }^{67}$ S. Clauwaert and I. Schomann, op. cit., at 10 \& 14.

${ }^{68}$ I. MacNeil, "The Trajectory of Regulatory Reform in the UK in the Wake of the Financial Crisis", (2010) 11 European Business Organisation Law Review, pp. 483-526, at 484.

${ }^{69}$ H. Chung and S. Thewissen, "Falling Back on Old Habits? A Comparison of the Social and Unemployment Crisis Reactive Policy Strategies in Germany, the UK and Sweden”, (2011) 45(4) Social Policy \& Administration, pp. 354-370, at 358 \& 362.

${ }^{70}$ B. Vis, K. van Kersbergen and T. Hylands, "To What Extent Did the Financial Crisis Intensify the Pressure to Reform the Welfare State?" (2011) 45(4) Social Policy \& Administration, pp. 338-353, at 347.

${ }^{71}$ B. Hepple, "Back to the Future: Employment Law under the Coalition Government", (2013) 42(3) Industrial Law Journal, pp. 203-223, at 207.
} 
employer company to waive certain employment rights such as the right not to be unfairly dismissed, the right to statutory redundancy pay, entitlement to request flexible working except in limited circumstances, and the entitlement to request training or study. Employee-shareholders are also subject to longer notice periods before returning from maternity or paternity leave. While the waiver of employment rights does not preclude claims relating to discrimination and employees are required to take independent legal advice, entitled to a detailed statement of terms and subject to a seven day cooling off period, the implications of this new form of contract essentially undermines the cornerstone of UK employment law: the employment contract. ${ }^{72}$ It is yet to be seen what effect this new status may have on the equality in the employment relationship, bargaining power and the relative security of employment.

While most countries have taken action in relation to benefits for the unemployed affected by the financial crisis, Britain has taken a decidedly apathetic approach. It had the least supportive system for the unemployed prior to the crisis and has proved to be the most reluctant government to improve its policies in the light of the economic conditions of the crisis. Instead, Britain has introduced employment subsidy schemes to benefit employers hiring the long term unemployed and focussed on other means of activating the unemployed in the country. ${ }^{73}$

\section{i) Wages}

The lack of intervention by the UK government led to the involvement of social partners in entering into collective agreements that reduced working hours and wages in order to save jobs, though in many cases massive redundancies were still unavoidable. The median pay settlement dropped and occupational pensions have been cut. $^{74}$

\section{ii) Atypical Contracts}

Zero-hours contracts have become in common usage in the UK. These contracts mean that there is no obligation on the employer to provide work or for workers to accept it, but it also often means that employees are not permitted to work for another employer at the same time, leaving them in a precarious financial position. While a flexible workforce is one of the reasons cited for the UK pulling away from France and the rest of the Eurozone in terms of GDP growth, but the zero hours contract may also be creating a low-wage underclass to be summoned peremptorily by

\footnotetext{
${ }^{72}$ J. Prassl, "Employee Shareholder "Status: Dismantling the Contract of Employment", (2013) 42(4) Industrial Law Journal, pp. 307-337, at 312-315 and J.-F. Gerard, op. cit.

${ }^{73}$ D. Clegg, op. cit., at $5 \& 9$.

${ }^{74} \mathrm{H}$. Chung and S. Thewissen, op. cit., at 363.
} 
employers on a whim in a repeat in what might be recognised as a Victorian style industrial relationship. ${ }^{75}$

\section{iii) Hiring and Firing}

In the UK, unfair dismissal rules have been substantially changed. Employees must now work for a minimum of two years continuous service to qualify to claim unfair dismissal at an Employment Tribunal. Compensation has also been restricted to the lower of a specified amount not exceeding three times the median annual earnings of an employee or a specified number of not less than 52 weeks multiplied by a weeks' pay of the employee. ${ }^{76}$

\section{iv) Redundancy and Acquired Rights}

The global economic crisis has inevitably led to redundancies in the workplace, particularly relevant in those jurisdictions, such as the United Kingdom, that have relatively weak protections in place against collective dismissals. ${ }^{77}$ The UK has undertaken to comply only minimally with EU obligations for worker protective obligations. Conditions governing economic dismissals have been softened and thresholds loosened in order to increase labour market flexibility, making it easier for businesses to lay off workers. ${ }^{78}$ In particular, it has reduced the consultation period for collective dismissals from 90 to 45 days for redundancies of more than 100 employees (the EU minimum is 30 days) and now excludes fixed term contracts that have reached their agreed termination date from collective redundancy obligations. ${ }^{79}$ There have also been reduced protections under the TUPE regulations ${ }^{80}$ : contractual conditions can now be more easily altered if the changes are connected with the transfer but are for an economic, technical or organisational reason entailing changes in the workforce; dismissals are no longer automatically unfair for changes in workplace; collective agreements can be renegotiated a year after the transfer; and it is now more difficult to satisfy the criteria of a service provision change (the work must be fundamentally the same).$^{81}$

\footnotetext{
${ }^{75}$ ACAS Advice and Guidance Web-Pages, "Zero-Hours Contracts" available from $<$ http://www.acas.org.uk/zerohours> first accessed 15 August 2014.

${ }^{76}$ B. Hepple, op. cit., at 207-208.

${ }^{77}$ A. P. Nascimento, op. cit., at 50.

${ }^{78}$ M. Magone, "Portugal" (2009) 48 European Journal of Political Research, pp. 1080-1086, at 1081.

${ }^{79}$ B. Hepple, op. cit., at 207-208.

${ }^{80}$ The Transfer of Undertakings (Protection of Employment) Regulations 2006, no. 246.

${ }^{81}$ ACAS "2014 Changes to TUPE” (2014) Ref AL20 available from <http://www.acas.org.uk/media/pdf/1/1/9908-2901767-TSO-ACAS-TUPE_is_changingACCESSIBLE.pdf $>$ first accessed 26 September 2014
} 


\section{v) Access to Social Welfare}

In Britain there has been a nearly complete absence of any improvement in income support measures. ${ }^{82}$ In fact, it has become increasingly difficult for the most vulnerable in society to access social benefits associated with loss of employment and disability.

\section{vi) Access to Justice}

The UK has had a highly flexible labour market in comparison to the rest of the EU member states for decades. However, it could be said that the financial crisis and its effects on labour markets throughout the EU has provided an opportunity to further reduce employment rights through deregulation. Most significant perhaps is the fact that the UK has made it more difficult for employees to access justice for unfair dismissal and indeed any other employment related claim by instituting fees for employment tribunals and appeals. The introduction of tribunal fees affects not only unfair dismissal claims, but those relating to discrimination and other socially important aspects of employment law. ${ }^{83}$

\section{Impact of Financial Crisis on Rescue Regimes}

There have been a number of reforms to insolvency and corporate rescue throughout the EU in the early 2000's and then just following the financial crisis with aims of supporting a rescue culture, though the various regimes under examination here have found themselves at different depths along the stream of rehabilitation and recovery. These regimes have operated with varied success as an effective embankment for the protection of failing businesses and the social and economic welfare associated with them. For the purpose of this paper, the focus of attention will be on preinsolvency rescue procedures.

\section{Greece}

Prior to the reforms of 2007, Greece lacked any kind of sophisticated corporate rescue regime. Rather its insolvency system was geared toward liquidation and has historically resembled the French insolvency system. Rehabilitation under the old system was only theoretically possible through a settlement of debts between the debtor company and its creditors by way of a voluntary reorganisation through a

\footnotetext{
${ }^{82}$ D. Clegg, op. cit., at 10.

${ }^{83}$ S. Clauwaert and I. Schomann, op. cit., at 14.
} 
direct creditors' agreement, though this method did not provide for a "cram-down" 84 on dissenting creditors. ${ }^{85}$

The 2007 Insolvency Law ${ }^{86}$ aimed to update an outdated system by introducing radical changes to the Greek insolvency philosophy, providing for the rescue of ailing companies and offering a second chance to insolvent debtors. It provided for quick and easy access to rehabilitation procedures such as conciliation and was primarily designed to ensure the rescue of viable distressed companies and preservation of employment. Conciliation was a debtor in possession procedure similar to the French conciliation procedure. A debtor in financial difficulties would apply to the court to appoint a conciliator with the task of achieving an agreement between the debtor company and its creditors in order to overcome the company's financial distress and safeguard its survival. ${ }^{87}$ The debtor would then be immune to individual enforcement for a period of two years while the reorganisation plan was being implemented. However, the conciliation proceeding proved inadequate to the task due to its consensual basis and lack of cram-down. The requirement to appoint a conciliator or mediator also led to a lengthy process that made it impossible to bring the parties to agreement quickly. In addition, the conciliation procedure has been abused by debtors as a means of securing a preliminary order prohibiting creditors from enforcing their claims. ${ }^{88}$

In 2011, a new law was passed that replaced conciliation with rehabilitation. This revised procedure allows a debtor to obtain the ratification of a restructuring plan agreed with the requisite majority of creditors without any other judicial assistance or protection. The debtor can also submit an application for the opening of negotiations with creditors in which it can seek the appointment of a mediator to facilitate negotiations or it can seek to negotiate directly with a creditors' committee, or on a bilateral basis where a qualified majority of creditors negotiate directly with the debtor company. This procedure is technically pre-bankruptcy, but a company must show that it is in a state of financial weakness. A moratorium can also be put into place through a preliminary order by the court after an application for rehabilitation proceedings has been received. ${ }^{89}$

While the new rehabilitation procedure is a clear improvement over the conciliation procedure, it also has serious obstacles to overcome in order for it to make any significant contribution to rescuing companies, saving jobs and maximising value for the financially distressed debtor company's stakeholders overall. Access to the procedure is draconian, restricted to companies just on the verge of insolvency and that have perhaps already gone too far down the river to be rescued. The process is also still overly dependent on the Greek judicial system.

\footnotetext{
${ }^{84}$ Defined as the involuntary imposition by a court of a reorganization plan over the objection of some classes of creditors.

${ }^{85}$ A. Kastrinou, "European Corporate Insolvency Law: An Analysis of the Corporate Rescue Laws of France, Greece and the United Kingdom" (2009) Thesis submitted for the degree of Doctor of Philosophy at the University of Leicester, at 170-204, 171-172 \& 190-194.

${ }^{86}$ Law 3588/2007 enacted on 10 July 2007.

${ }^{87}$ A. Kastrinou, Ibid.

${ }^{88}$ A. Potamitis and A. Rokas, “A New Pre-Bankruptcy Procedure for Greece” (2012) 3 Journal of Business Law, pp. 235-247, at 235-237.

${ }^{89}$ Ibid., 237-241.
} 
While a pre-pack style of procedure is available in Greece, it requires a number of months and contested hearings under Greek procedural requirements. Greek business culture is also an issue given that the success of a rescue proceeding depends on a residual trust and good faith among the debtor and its stakeholders. Greek business culture tends to be suspicious of these processes, viewing them as a prelude to default and often precipitating damaging responses from suppliers and banks. The abuse of the previous system does not help in this negative view. ${ }^{90}$

\section{Portugal}

Rescue proceedings in Portugal are available in the Insolvency Plan, an out of court proceeding similar in form to the German Insolvenzplan as set out in the Insolvency and Enterprise Rescue Code ${ }^{91}$ in 2004. The purpose of this procedure is either to liquidate an insolvent debtor's assets and distribute the proceeds to creditors or to satisfy creditor debt in a manner envisaged in an insolvency plan based on the recovery of the company. However this plan was available only available if the company was indeed insolvent, thus not technically a pre-insolvency rescue procedure. $^{92}$

The Portuguese MoU required that reforms be instated that better facilitate the rescue of viable firms, including fast-tracking court approval procedures for restructuring plans. Thus Portuguese legislators introduced reforms in 2012 that added a new hybrid proceeding to the insolvency plan aimed only at pre-insolvency situations, the special revitalisation proceeding. It is available to those companies that are facing economic difficulties or are in an imminent insolvency situation. The procedure is comprised of a period of negotiations between the company and its creditors with the aim of agreeing to a restructuring plan. Once agreed by a qualifying majority of creditors and approved by the court, the plan becomes binding upon all creditors, whether dissenting or not. ${ }^{93}$ Since its implementation, the new revitalisation procedure has seemed popular among a number of different debtors, company and individual alike. ${ }^{94}$

There are, however, certain weaknesses in this new procedure. While it is advantageous that the restructuring can now be carried out without the company being declared insolvent, in the event that negotiations do not arrive at an equitable solution, the company then risks being declared insolvent and subject to the opening

\footnotetext{
90 Ibid., 246-247.

${ }^{91}$ Decreto-Lei 200/2004.

92 A. P. Matos Martinas and M. J. Andrade Campos, "Portugal" Chapter 3 in C. Mallon (ed), The Restructuring Review (2010, Law Business Research Ltd, London), pp. 275-287, at 276-277.

${ }^{93}$ C. Serra, “The Rescue of Large Corporations-How Suitable is the Portuguese Insolvency Act?” in R. Parry (ed.), Too Big to Fail? Large National and International Failures under the Spotlight (2013, INSOL Europe, Nottingham), pp. 97-105, at 97-99.

${ }^{94}$ C. Serra, "In the Eye of the Crisis - A Portuguese Perspective" (2013) Second Quarter INSOL World - The Quarterly Journal of INSOL International, pp. 24-25.
} 
of insolvency proceedings. ${ }^{95}$ Part of the problem here is that, like Greece, there is a cultural suspicion of debt and insolvency. If the debtor is unable to satisfy the creditors that any compromises made will be worth the result, those creditors might well initiate insolvency proceedings in order to protect themselves from what they may view as an untenable or even unscrupulous process. The 2012 reforms did, however, make changes to the requirements for classification in insolvency, which had before been associated with the finding of guilt for those causing the financial troubles. It is now no longer compulsory to register for classification unless there is evidence of intentional or grossly negligent conduct by the company directors. ${ }^{96}$

The 2012 amendments did not, however, provide any reformative measures for the insolvency plan, despite the undisputed flaws in the regime. Thus it remains equally difficult for insolvent companies, even though still viable, to escape liquidation. The absence of amendments to the insolvency plan, in addition to the shortening of the term to file for insolvency, make a company's position under Portuguese insolvency law that much more pressured rather than alleviating the stress. ${ }^{97}$ Where difficulties for businesses are encountered, so too are risks for employees.

\section{France}

France might be considered the inventor of the concept of corporate rescue, beginning in 1967 even prior to the legendary Chapter 11 procedure of the United States that many systems now try to emulate. In the 1990s the mandataire ad hoc and the amicable settlement provided preventative pre-insolvency procedures. The Law of $2005^{98}$ revised the ad hoc mandate and replaced the amicable settlement with conciliation. The conciliation procedure is a type of mediation open to businesses in foreseeable or acknowledged difficulty as well as those already in a state of cessation of payments. The procedure gives creditors the opportunity to agree a legally binding agreement with the debtor company. ${ }^{99}$ The Law of 2005 also introduced the procedure of sauvegarde (preservation) as an up-stream option to the conciliation and ad hoc procedures, aimed at early intervention in a failing company. However, and without leaving much time for the new procedure to become integrated into practical usage, its perceived underutilisation led to a reform in 2008. The ordinance of $2008^{100}$ made major changes to all of the procedures contained within the French

\footnotetext{
${ }^{95}$ C. Serra, "The Rescue of Large Corporations-How Suitable is the Portuguese Insolvency Act?" op. cit., at $97-99$.

${ }^{96}$ C. Serra, "Country Reports: Portugal - the New Portuguese Insolvency Act" (2012) 47 EuroFenix The Journal of INSOL Europe, pp. 40.

${ }^{97}$ C. Serra, "Amendments to the Portuguese Insolvency Act - Much ado about nothing?" (2012) 49

EuroFenix - The Journal of INSOL Europe, pp. 14-17.

${ }^{98}$ Law No. $2005-845$ of 26 July 2005.

99 J. R. Silkenat and C. D. Schmerler, The Law of International Insolvencies and Debt Restructurings (2006, Oceana Publications, United States), at 146-150.

${ }^{100}$ Ordinance no. 2008-1345 of 18 December 2008.
} 
insolvency system. The bulk of its provisions addressed the perceived deficiencies of the sauvegarde procedure. ${ }^{101}$

The global financial crisis also led to changes in practice that prompted further reforms in the Law of $2010,{ }^{102}$ introducing a French style of pre-pack in a new procedure called the sauvegarde financière accélérée (accelerated financial preservation). Designed mainly for larger companies, it allowed a company undergoing conciliation to enter into the sauvegarde if they had a plan that they could convince the court would assure the continuation of the business and command the support of a majority of creditors. These procedures, out of the range available among the four jurisdictions under study in this paper, appear to be the most advanced, up-stream, pre-insolvency procedures available, perhaps throughout the whole of the EU. However, the continued impact of the financial crisis, the impact of the Eurozone crisis, concerns about the continued viability of French businesses and chronic underemployment has led to yet another set of reforms in 2014. This was preceded by a review and a report on the state of insolvency that stated that the principal objectives for any reform would be to facilitate the anticipation of worsening economic conditions by businesses, to reinforce the efficiency of procedures by adjusting the impact to creditors, debtors and others, to adapt to the prevailing reality of the treatment of businesses in an irremediable and compromised situation while at the same time respecting the relative rights of creditors and debtors as well as to ensure greater security, simplicity and effectiveness. ${ }^{103}$ The result was an Ordinance of $2014^{104}$ that introduced two new procedures: sauvegarde financière and the rétablissement professionnel, both of which are dependent upon another procedure previously being engaged. The former is a variation on the sauvegarde theme as an agreement among the principal creditors and the debtor and contains a cram-down element while the latter deals with impecunious estates. The sauvegarde financière has the advantage of speed and efficiency in terms of not losing business value and is intended not to affect employees at all. ${ }^{105}$

While the frequency of reform in France is great and perhaps, due to that fact, confusing, it also shows a willingness to change with the time in such a way as to keep improving the effectiveness of corporate rescue processes. France's inherent concern for its workers is also supported by the constant improvement of corporate rescue as this inevitably assists in maintaining a higher level of job security, which is a stated objective of the French rescue culture.

\footnotetext{
${ }^{101}$ P. Omar, "A Reform in Search of a Purpose: French Insolvency Law Changes (Again!)” (2014) 23(3) International Insolvency Review, pp. 201-220 at 202-204.

${ }^{103}$ Rapport au Président de la République relative à l'ordonnance no. 2014-326 du 12 mars 2014 portant réforme de la prévention des difficultés des entreprises et des procédures collectives ("Presidential Report"), in the Introduction.

104 Ordinance no. 2014-326 of 12 March 2014.

${ }^{105}$ P. Omar, op. cit., at 205.
} 


\section{United Kingdom}

The most significant reforms to insolvency law in the United Kingdom in the recent past occurred five years before the beginning of the crisis with the Insolvency Act $2000^{106}$ Enterprise Act 2002, both of which came into force on 2 November 2002. ${ }^{107}$ These acts modified the Insolvency Act 1986 by replacing certain of its provisions with new sections and schedules aimed at improving rescue procedures in terms of efficiency, benefit and practical use. The 2000 Act reformed the Company Voluntary Arrangements, a pre-insolvency procedure which now allows for a moratorium, while the 2002 Act reforms the administration procedures. The latter of theses has arguably had the most significant effect on the UK rescue culture as it went further to protect unsecured creditors, streamlined the procedures, and was implemented despite the resistance of banks, financial institutions and other primary lenders who had benefitted from the exclusive control that administrative receivership had allowed. ${ }^{108}$ The new procedure presents three hierarchical objectives: to first try to rescue the company as a going concern, or if not to achieve a better result than would be achieved in liquidation. Finally, if the first two options were unattainable, seek to realise property in order to make distributions to secured or preferential creditors. ${ }^{109}$ It is not, however, a pre-insolvency procedure in its purely statutory form.

The pre-pack, however, does function as a pre-insolvency type of mechanism, though it is a non statutory practice led process that functions on the premise of a pre-packaged sale by an administrator on terms that have been agreed before the administration is commenced, but which is carried out shortly after the appointment of an administrator. ${ }^{110}$ This process avoids the disruption to business common in normal insolvency procedures and also reduces the potential reputational damage due to its secretive nature. While the secretive nature of pre-packs have come under scrutiny in recent years, particularly with regard to their effects on employment protection in these satiations, they are still commonly used and an important element of the UK's pre-insolvency procedures. ${ }^{111}$ While true that UK case law has said that TUPE would apply to transfers occurring out of pre-pack administrations, ${ }^{112}$ in practice this has not been a particularly serious issue due to the way that pre-packs are used: mainly as a tool for debt restructuring. ${ }^{113}$

\footnotetext{
${ }^{106}$ Insolvency Act 2000 , c. 39.

${ }^{107}$ Enterprise Act 2002, c. 40 .

108 The Enterprise Act 2002 also abolished administrative receivership which was a procedure that could be initiated by a floating charge holder holding security over all or most of the company's assets through which it could appoint an administrative receiver to act on their behalf to exercise their security rights, putting them in control of the company assets and generally leading to liquidation and low to no returns for other creditors.

${ }^{109}$ P. Omar and J. L. L. Gant, "Corporate Rescue in the UK: Ten Years after the Enterprise Act 2002 Reforms", (2014) (forthcoming).

${ }^{110}$ D. Ereira, "UK Restructuring and Insolvency Law: Current and Future Trends", (2010) April

Practical Law Publishing Limited, pp. 23-29.

${ }^{111}$ K. Creighton-Selvay, "Pre-packed Administration: an Empirical Social Rights Analysis", (2013)

42(2) Industrial Law Journal, pp. 85-121, at 88

${ }^{112}$ See Key2Law v De'Antiquis \& Anor [2011] EWCA Civ 1567.

${ }^{113}$ K. Creighton-Selvay, op. cit, at 112.
} 
The Company Voluntary Arrangement is another pre-insolvency mechanism that is sometimes used on its own and sometimes in conjunction with an administration or a pre-pack procedure. The purpose of the CVA is to avoid a formal insolvency procedure that would otherwise consume the assets of the company. As a debtor friendly procedure, it also encouraged companies to seek help at an earlier stage of their difficulties. ${ }^{114}$ In addition to this, the Scheme of Arrangement, ${ }^{115}$ although not technically within the remit of the insolvency regime, provides another mechanism through which companies can deal with their financial problems at an earlier stage. Thus there are a number of options for up-stream pre-insolvency procedures in the UK, providing a means of preserving business and, by association, employment. However, the employment protection regime in the UK does not provide a high level of protection that can be depended upon in insolvency situations.

\section{Conclusion}

Employment protection and corporate rescue reforms differ in their fundamental functions, but are both important aspects of a healthy economy. Excessive inequalities in terms of wages and productivity have been said to be at the root and economic recessions and depressions during the modern era. Such imbalances heighten the risk of economic failure. A growing wage and productivity gap upsets the natural mechanisms necessary to achieve economic balance. Where wages fall, so too does consumption, leading to deflation where demand is not supported. ${ }^{116}$ This also applies to the economic benefit of unemployment insurance as this helps to stabilise consumer demand in the face of economic downturns, which would otherwise be sapped by rising unemployment. ${ }^{117}$

While employment protection and other socially oriented regulation provide an important safety net for employees who are in an inherently less powerful bargaining position than employers generally, the financial crisis has seen these measures reduce in strength throughout the EU, except exceptionally perhaps for France. As these measures reduce in strength, employee rights in insolvency also fall behind as redundancy, dismissal, collective agreements and transfer of undertakings are often implicated in insolvency and rescue processes. If one looks at corporate rescue not only as a means of preserving economically viable businesses, but also as a part of the social aims of employment protection, there arises an additional reason to ensure that corporate rescue processes are effective: the protection of the employees. The rescue culture might provide another level of employment protection, an embankment against the ravages of economic recession and crisis, in

\footnotetext{
${ }^{114}$ P. Omar and J. L. L. Gant, "Corporate Rescue in the UK: Ten Years after the Enterprise Act 2002 Reforms", (2014) (forthcoming).

115 Section 895, Companies Act 2006, c. 46

${ }^{116}$ S. Lansley, "Inequality, the Crash and the Ongoing Crisis", (2012) 83(4) The Political Quarterly, pp. 754-761, at 756-757.

${ }^{117}$ D. Clegg, "Labour Market Policy in the Crisis: the UK in Comparative Perspective", (2010) 18(1)

The Policy Pressm, pp. 5-17, at 8.
} 
which an effective rescue system might help to alleviate some of the severity of the effects that the financial and sovereign debt crisis have had on the rights and security of employees and workers. 